JADWIGA KUCZYŃSKA-KWAPISZ

Wydział Nauk Pedagogicznych

Uniwersytet Kardynała Stefana Wyszyńskiego w Warszawie

ORCID ID: http://orcid.org/oooo-00o2-0341-1062
Forum Pedagogiczne 9(2019) 1

Wpłynęło: 8.01.2019

Zatwierdzono do druku: 24.04.2019 DOI: 10.21697/fp.2019.1.06

\title{
MARZENA DYCHT
}

Wydziat Nauk Pedagogicznych

Uniwersytet Kardynała Stefana Wyszyńskiego w Warszawie

ORCID ID: http://orcid.org/oooo-00o2-8283-6770

\section{MYŚL I PRAKTYKA TYFLOPEDAGOGICZNA MATKI ELŻBIETY - RÓŻY CZACKIEJ}

\begin{abstract}
Streszczenie: W artykule przedstawiono fakty z życia Róży Marii Czackiej i jej działalność. Matka Elżbieta Róża Czacka była prekursorką edukacji i rehabilitacji osób niewidomych i słabowidzących w Polsce; twórczynią nowoczesnych, wzorcowo funkcjonujących instytucji, będących praktyczną egzemplifikacją jej teoretycznych koncepcji i założeń. Scharakteryzowano również dzieło Matki Elżbiety, uwzględniając jego kontekst naukowy i pragmatyczny. Tyflologiczne i socjalne inicjatywy, niosące wsparcie osobom z dysfunkcją wzroku oraz aktywność w tworzeniu globalnych, systemowych rozwiązań w dziedzinie polityki społecznej i oświatowej dotyczącej tej grupy osób z niepełnosprawnością, sytuują Różę Marię Czacką w gronie postaci znaczących dla polskiej pedagogiki specjalnej, w tym zwłaszcza tyflopedagogiki.
\end{abstract}

Słowa kluczowe: Róża Czacka; Matka Elżbieta; osoba niewidoma; słabowidząca; kształcenie.

\section{Wstęp}

W dziejach ludzkości szczególną rolę odgrywają ludzie wielkiego umysłu, którzy odkrywają nowe przestrzenie badawcze, kreują nowe dziedziny wiedzy i dyscypliny nauki, są twórcami nowatorskich teorii i koncepcji, umożliwiając tym samym pełniejsze zrozumienie otaczającej ich rzeczywistości. Dzięki ich badawczym pomysłom, oryginalnym tezom, propozycjom teoretycznych ujęć i praktycznych rozstrzygnięć możliwy staje się rozwój nauki i poprawa społecznego dobra. W szczególnych dla życia ludzkości momentach - dzięki poglądom i dokonaniom tych twórczych prekursorów i skupionych wokół nich oddanych 
sprawie osób - możliwa staje się korzystna zmiana sytuacji życiowej różnych grup społecznych, zwłaszcza tych zagrożonych wykluczeniem czy marginalizacją z powodu biedy, zaburzeń rozwoju i trudności adaptacji społecznej.

Taką postacią w polskiej pedagogice specjalnej, a zwłaszcza tyflopedagogice, jest Róża Maria Czacka, która to pierwsza w Polsce nie tylko opisała wszechstronnie sposób edukacji i rehabilitacji osób niewidomych i słabowidzących, lecz także utworzyła nowoczesne, wzorcowo funkcjonujące instytucje, w których praktycznie wdrożyła w życie własne teoretyczne koncepcje. W pierwszej części artykułu przedstawimy fakty z życia R. Czackiej, które miały wpływ na jej działalność tyflologiczną, a także jej osiągnięcia, zarówno w zakresie teorii, jak i praktyki. Następnie scharakteryzujemy jej Dzieło, uwzględniając jego kontekst naukowy i pragmatyczny.

\section{Róża Czacka - Matka Elżbieta - życie i działalność prekursorki polskiej tyflologii}

Róża Maria Czacka, znana także jako Matka Elżbieta Czacka (1876-1961) w roku odzyskania przez Polskę niepodległości miała 42 lata. Początek działalności R. Czackiej na rzecz osób niewidomych miał miejsce jeszcze w czasie zaborów, dynamiczny natomiast rozwój Dzieła i jego rozmaitych działów oraz tworzenie ideowych jego fundamentów przypadają na okres już niepodległej II Rzeczypospolitej. R. Czacka urodziła się w Białej Cerkwi (obecnie Ukraina). Tam spędziła pierwsze lata dzieciństwa. W roku 1882 rodzina zamieszkała w Warszawie, wyjeżdżając często do rodzinnych majątków na Wołyniu. Wychowywała się w atmosferze wielkich tradycji patriotycznych i społecznych związanych w dużej mierze z Wołyniem. Jej pradziadkiem był Tadeusz Czacki - jeden z najważniejszych obrońców polskiej kultury w epoce rozbiorów, wybitny działacz Sejmu Czteroletniego, Komisji Edukacyjnej oraz założyciel znanego Liceum Krzemienieckiego, które tak ważną rolę odegrało jako ośrodek kultury i oświaty na Wołyniu. R. Czacka w działalności pedagogicznej odwoływała się do zasad wychowania obowiązujących w Liceum Krzemienieckim (Kuczyńska-Kwapisz 2011). Tradycja społeczna była utrzymywana w rodzinie także przez ojca R. Czackiej - Feliksa Czackiego. Miał on duże poczucie dobra wspólnego. Należał do licznych organizacji społecznych. Angażował się w pracę Towarzystwa Dobroczynności, Szpitalika Dziecięcego, Towarzystwa Kredytowego, budowę kolei Warszawsko-Wiedeńskiej. Był właścicielem ziemskim. Znał się dobrze na rolnictwie i przemyśle spożywczym. Róża często towarzyszyła ojcu w pracy i omawiała $\mathrm{z}$ nim rozmaite przedsięwzięcia gospodarcze, a także społeczne. W ten sposób uczyła się różnych dziedzin praktycznego życia, podstaw prawa, organizacji i sposobów zarządzania. Wykształcenie ogólne i naukę języków obcych otrzymywała w domu, rodzice zatrudniali bardzo dobrych nauczycieli, także z zagranicy, m.in. z Francji. Róża zdobyła wiedzę gruntowną i wszechstronną. Właśnie to wielostronne i praktyczne przygotowanie pozwoliło później 
R. Czackiej utworzyć dużą instytucję i nią kierować. Doskonała znajomość języka francuskiego ułatwiła jej szerokie kontakty z najlepszymi tyflologami, literaturą naukową i poradnikową z zakresu tyflopedagogiki i tyflopsychologii. Z pewnością nie bez znaczenia dla jej dalszej działalności było zaangażowanie religijne członków jej rodziny i wyniesione z domu wychowanie katolickie. Ważny był fakt, że brat ojca - Włodzimierz, był kardynałem, sekretarzem, przyjacielem i doradcą papieży: Piusa XI (wcześniej znany jako Ambrogio Damiano Achilles Ratti był Nuncjuszem Apostolskim w Polsce), a potem Leona XIII. Bezpośrednio od Achillesa Rattiego otrzymała wskazówki dotyczące organizacji i funkcjonowania placówek dla niewidomych.

Istotną rolę w życiu R. Czackiej odegrała jej babka od strony ojca. Ona to zajęła się wychowaniem religijnym Róży. Pierwsza zwróciła uwagę na zagrożenie dla wzroku wnuczki i jednocześnie zaczęła przygotowywać ją duchowo do trudnej sytuacji utraty wzroku, a także praktycznie do radzenia sobie bez wzroku w wykonywaniu codziennych czynności. Róża od dzieciństwa miała wysoką krótkowzroczność, a później nabytą i postępującą jaskrę. Upadek z konia, w wieku 22 lat, przyspieszył odwarstwienie siatkówki i w konsekwencji spowodował utratę wzroku. Rodzice jeździli z nią do najlepszych okulistów w kraju i za granicą. Trudno im było pogodzić się z tą ciężką sytuacją, długo ukrywali przed otoczeniem nieodwracalną prawdę. Okulista, dr Bolesław Ryszard Gepner, powiedział R. Czackiej, że nie ma sposobu na uratowanie jej wzroku. Jednocześnie poradził, żeby zajęła się sprawami osób niewidomych, którymi nikt w Polsce się nie zajmuje. Początkowo taka perspektywa ją przeraziła, ale już po kilku dniach była bardzo wdzięczna za przekazaną prawdę i postawione przed nią wyzwanie. Poprzez swoje cierpienie odkryła powołanie do pomocy innym niewidomym. Zaczęła gruntowne przygotowania do tego celu. W pierwszej kolejności rozpoczęła od własnej rehabilitacji. Nauczyła się czytać i pisać brajlem. Poznała sytuację niewidomych w Królestwie Polskim. Interesowała się sposobem rozwiązywania pomocy niewidomym w innych krajach, w tym celu sprowadzała książki tyflologiczne i prenumerowała czasopisma specjalistyczne w różnych językach wydawane w brajlu i czarnym druku. Nie ograniczyła się jedynie do literatury, lecz zaczęła podróżować, aby poznać zagraniczne placówki wiodące w zakresie opieki nad niewidomymi oraz nawiązać kontakty z ludźmi mającymi doświadczenie i wiedzę tyflologiczną. W tym celu była w Wiedniu, Szwajcarii, Francji, a później we Włoszech. We Francji powstała pierwsza szkoła dla dzieci niewidomych, został opracowany alfabet brajlowski, pomoce dydaktyczne i niezwykle prężnie działająca organizacja Association Valentin Haüy pour le bein des aveugles. Róża Czacka poznała tam Maurice de la Sizeranne’a pomysłodawcę i założyciela tej nowoczesnej instytucji, zmieniającej gruntownie podejście do spraw osób niewidomych. Jego wskazaniem do pracy na rzecz osób z dysfunkcją wzroku była teza: „niewidomy - człowiekiem użytecznym”. Zamiast przyjętych dotychczas form opieki filantropijnej, prowadzącej osoby niewidome do dużej bierności, wskazał on nową drogę, wiodącą do ich aktywności zawodowej 
i integracji społecznej oraz wzięcia odpowiedzialności za swoje życie. Uważał, że obowiązkiem państwa i społeczeństwa jest pomoc niewidomym w zdobyciu wykształcenia ogólnego i zawodowego. Koncepcja ta odpowiadała poglądom R. Czackiej. Ona to, poprzez swoją działalność, popularyzowała hasło: „niewidomy - człowiekiem użytecznym", upowszechniała ideę pełnego, wszechstronnego rozwoju możliwości i zdolności niewidomego; była jedną z pierwszych, osób które konstruowały zręby polskiej tyflologii i postrzegały ją jako naukę o niewidomych $\mathrm{i}$ ich wszechstronnej rehabilitacji.

Okres przygotowań do rozpoczęcia pracy na rzecz osób niewidomych trwał 1o lat. Świadczy to o dużej odpowiedzialności Róży Czackiej za sprawy niewidomych, chęci uzyskania jak najlepszej wiedzy tyflologicznej, a także o dokładności w działaniu i cierpliwości. Od 1908 roku podjęła pierwsze próby praktycznej realizacji własnej koncepcji pracy na rzecz ludzi niewidomych na ziemiach polskich. O swoich motywach pisała: „chcąc dać innym niewidomym to szczęście, które posiadam sama - Wiarę, której zawdzięczam przyjęcie ślepoty z poddaniem się woli Bożej, myślałam o stworzeniu instytucji umożliwiającej osiągnięcie tego celu. W ciągu dziesięciu lat przygotowywałam się do tej pracy, czekając chwili odpowiedniej do realizacji planu, który powoli dojrzewał" (cyt. za Kuczyńska-Kwapisz 2011, s. 195).

Zaczęła od indywidualnej pomocy kobietom niewidomym, później tworzyła kolejne i ciągle rozbudowujące się instytucje. Pierwsza organizacja, utworzona przez Różę Czacką, to w roku 1910 Towarzystwo Opieki nad Ociemniałymi (TOnO) w Warszawie, oficjalnie ukonstytuowane i zatwierdzone przez władze carskie w 1911 roku. Założycielka na działalność tej instytucji przeznaczyła własne fundusze oddziedziczone po rodzicach. Później dbała o zabezpieczenie finansowe Towarzystwa, organizując kwesty publiczne, zwracając się do różnych osób z prośbą o ofiary i zabiegając o dotacje państwowe. Zadaniem TOnO była działalność zorientowana na powołanie patronatu sprawującego opiekę nad niewidomymi i ich rodzinami, utworzenie ochronki dla niewidomych dzieci, założenie szkoły dla niewidomych chłopców - po raz pierwszy w Polsce uczono w niej pisania brajlem w języku polskim, organizację kolonii letnich dla tych dzieci, zorganizowanie biura przepisywania książek brajlowskich. W celu utrzymania katolickiego rozwoju zakładanych instytucji i zapewnienia realizacji procesu wychowania zgodnego z nauką Kościoła, a także spełnienie własnego powołania, Róża Czacka utworzyła nowe zakonne Zgromadzenie Sióstr Franciszkanek Służebnic Krzyża i została jego przełożoną - Matką. Przyjęła imię zakonne - Elżbieta (Kuczyńska-Kwapisz 2018). Znamienne jest to, że Zgromadzenie SFSK powstało w 1918 roku, a więc w roku odzyskania przez Polskę niepodległości. Powstawały wtedy nowe zgromadzenia, np. Sióstr Benedyktynek Misjonarek, Sióstr Pasjonistek i wiele stowarzyszeń, które odpowiadały na aktualne wówczas potrzeby Polaków. Od 1918 roku Matka Elżbieta zajmowała się nadal kierowaniem i rozwojem Towarzystwa Opieki nad Ociemniałymi, lecz w ścisłym powiązaniu $\mathrm{z}$ formującym się Zgromadzeniem Zakonnym Sióstr Franciszkanek Służebnic Krzyża. 
Ważna i wspierająca rozwój Dzieła była przychylność wspomnianego już Nuncjusza Apostolskiego Achillesa Rattiego, późniejszego papieża Piusa XI i rady udzielone przez niego Matce Elżbiecie Róży Czackiej, a także za jego pośrednictwem pierwszy kontakt, a później długoletnia oraz bardzo cenna współpraca z ks. Władysławem Korniłowiczem. Matka pisze o kontakcie z przyszłym papieżem w takich słowach: „[...] miałam sposobność być przedstawioną A. Rattiemu, który odtąd z prawdziwie ojcowską dobrocią otaczał swoją opieką naszą instytucję i nowopowstające Zgromadzenie. Znał tego rodzaju zakłady niewidomych we Włoszech, rozumiał doskonale warunki i potrzeby tej pracy i zechciał łaskawie udzielić mi wiele cennych rad i wskazówek, które stanowią podstawę całego Dzieła. Za wzór organizacji życia postawił mi obecny Ojciec Święty dzieło św. Józefa Cottolengo «Piccola Casa della Providenza» w Turynie, które, jak wiadomo, stanowi rodzaj osiedla dla dziesięciu tysięcy kalek różnego rodzaju [...], znając warunki i potrzeby specjalne opieki nad niewidomymi, z przenikliwością i znajomością rzeczy, wskazał mi wzór dla całości Dzieła. Podkreślał on również konieczność otoczenia niewidomych ludźmi o wysokim poziomie intelektualnym oraz znaczenie przystosowania się do potrzeb swego czasu w pracy charytatywnej i apostolskiej" (cyt. za: Kuczyńska-Kwapisz 2011, s. 200-201).

Cenna dla rozwoju Dzieła była darowizna, jaką M. Elżbieta otrzymała od Antoniego Daszyńskiego, a mianowicie ziemia w Laskach pod Warszawą, na obrzeżach Puszczy Kampinoskiej, i tak stopniowo, od 1922 roku rozpoczęła się budowa nowego osiedla i kolejne placówki z Warszawy zastały przenoszone do Lasek. W prowadzeniu budowy i kierowaniu Towarzystwem Opieki nad Ociemniałymi bardzo pomocny okazał się Antoni Marylski.

Międzywojenne lata 20. i 30. stanowiły okres niezwykle intensywnej pracy M. Elżbiety i dynamicznego rozwoju Dzieła. Opieka nad niewidomymi przybierała coraz szersze rozmiary, przybywało coraz więcej osób z dysfunkcją wzroku, pracowników, współpracowników i przyjaciół. Powiększało się i umacniało Zgromadzenie Sióstr Franciszkanek Służebnic Krzyża. Matka przygotowywała dokumenty ideowe, opracowała Dyrektorium, prowadziła konferencje dla sióstr. M. Elżbieta znana jest $\mathrm{z}$ wielu inicjatyw tyflologicznych i socjalnych, niosących wsparcie osobom niewidomym w Polsce. Włączyła się aktywnie w tworzenie globalnych, systemowych rozwiązań w dziedzinie polityki społecznej i oświatowej dotyczącej osób niepełnosprawnych wzrokowo (Czacka 1932a). Postulowała tworzenie właściwego ustawodawstwa i jego odpowiedniej realizacji, dotowanie finansowe działań na rzecz osób niewidomych i słabowidzących. Kształcenie, wychowanie i rehabilitację osób niewidomych traktowała jako zagadnienia zasadnicze w całokształcie problematyki tyflologicznej. Opracowała także w tym okresie wiele zagadnień tyflologicznych, w szczególności dostosowała alfabet brajlowski do języka polskiego, uwzględniając zasady polskiej ortografii i utworzyła system skrótów. Zarówno alfabet, jak i skróty zostały przyjęte przez Ministerstwo Wyznań Religijnych i Oświecenia Publicznego do powszechnego i obowiązującego 
stosowania w Polsce. Zabiegała o powszechną realizację obowiązku szkolnego przez dzieci niewidome i słabowidzące ${ }^{1}$. Dostrzegała konieczność objęcia opieką dzieci $\mathrm{w}$ wieku do lat 3 oraz $\mathrm{w}$ wieku przedszkolnym, a ponadto podkreślała konieczność objęcia wsparciem rehabilitacyjnym osób $\mathrm{z}$ dysfunkcją wzroku i z dodatkowymi niepełnosprawnościami. Jako jedna z nielicznych w owym czasie mówiła o potrzebie kształcenia niewidomych na wszystkich szczeblach, $w$ tym także na poziomie średnim i wyższym (Kuczyńska-Kwapisz 2011). Ideę nauczania i opieki socjalnej nad osobami niewidomi opisała w memoriałach pisanych do władz (Czacka 1932a, 1932b, 1937, 1938; Czacka, Landy 1932). W latach 1931-1938, R. Czacka prowadziła także prace badawcze. Ich wynikiem są publikacje o zasięgu krajowym. Można je znaleźć w aneksie książki pt. Wkład Matki Elżbiety Róży Czackiej w rozwój tyflologii w kontekście wspótczesnej recepcji jej myśli (Kuczyńska-Kwapisz 2011). Autorką trzech z nich jest Matka Elżbieta Róża Czacka, natomiast artykuł dotyczący systemu Braille’a w Polsce Matka napisała wspólnie z s. Teresą Landy. Wszystkie te prace zawierają myśli ważne i wciąż aktualne w tyflopedagogice. Pierwsza z nich pt. Historia Triuno jest relacją Matki o początkach i rozwoju Dzieła, przygotowaną na 25-lecie Towarzystwa Opieki nad Ociemniałymi w 1936 roku. Trzy kolejne, zatytułowane: System Braille’a w Polsce, Książka niewidomego, Dziecko niewidome omawiają zagadnienia związane z kształceniem i wychowaniem dziecka niewidomego. Przedstawiają problem pisma Braille’a, adaptacji i wyboru książek dla osób niewidomych oraz edukacji uczniów z dysfunkcją wzroku. Artykuły te były opublikowane w czasopismach: „Szkoła Specjalna” i „Ku Szczytom”. R. Czacka wykształciła i wychowała osoby niewidome zrehabilitowane, aktywne społecznie, poprzez naukę zawodu i pracę dążące do samodzielności i samowystarczalności. Podkreślała rangę autonomii osób niepełnosprawnych wzrokowo. W latach międzywojennych szkoły laskowskie, w oparciu o najnowsze wymogi tyflologii, osiągnęły wysoki poziom nauczania, konkurencyjny dla szkół publicznych masowych. Ich absolwenci kontynuowali z powodzeniem naukę w szkołach dla dzieci i młodzieży widzącej (Grodecka 1996). Rozważając dokonania Matki, trzeba pamiętać, że przyjmowała odpowiedzialność za wszystkie sprawy niewidomych w wolnej Polsce, zajmowała się całością Dzieła, dbała o sprawy codzienne i o trudne sprawy finansowe. Jest to zdumiewające, że tak wiele dokonała, biorąc pod uwagę jeszcze to, że poza brakiem wzroku cierpiała na chorobę nowotworową, przechodziła w związku z tym trudny proces leczenia.

Pomyślny rozwój Dzieła osłabił wybuch drugiej wojny światowej. We wrześniu 1939 roku Matka Elżbieta podczas bombardowania Warszawy została ranna. Przeszła bolesną operację, jednak bardzo szybko powróciła do pracy. Część budynków w Laskach uległa zniszczeniu. Przed Powstaniem Warszawskim Matka

1 Postulaty Matki o objęciu wsparciem dzieci z uszkodzonym wzrokiem stanowiły w okresie międzywojennym swoiste novum - założenia rehabilitacji wzroku zaczęto w Polsce realizować praktycznie dopiero w latach 80. XX wieku. 
zdecydowała się na zorganizowanie szpitala przygotowanego do przyjęcia rannych powstańców. Osoby niewidome również włączyła do pracy przy pomocy rannym. Po zakończeniu działań wojennych Matka znów zaczęła kierować odbudową Dzieła. Jednak choroba i w związku z nią pogłębiający się brak sił nie pozwoliły jej na to. Na prośbę Matki ks. Prymas Stefan Wyszyński mianował jej zastępczynią, a w rok później (1950) Matką Generalną, s. Benedyktę Woyczyńską. Od tego czasu M. Elżbieta wspierała swoje Dzieło modlitwą. Umarła 15 maja 1961 roku.

Założycielka TOnO i Zgromadzenia Sióstr Franciszkanek Służebnic Krzyża opowiadała się za pracą tyflopedagogiczną uwzględniającą formację chrześcijańską, wspierającą niewidomych wychowanków w kształtowaniu charakteru, intelektu, kreatywności, estetyki, zdolnych do samorozwoju i współżycia w grupie. M. Elżbieta reprezentowała chrześcijański personalizm pedagogiczny, który stanowił podstawę formacyjną dla światopoglądu pedagogicznego osób współpracujących w Dziele. Był pewnego rodzaju tłem, ważnym w powiązaniu codziennej praktyki wychowawczej z apostolską rolą Lasek. Wraz z ks. Władysławem Korniłowiczem była jedną z prekursorek katolicyzmu otwartego na inteligencję.

Jej pracowite życie i działalność na rzecz osób niewidomych są doceniane również współcześnie, zarówno przez władze państwowe, jak i kościelne. Postanowieniem prezydenta Lecha Kaczyńskiego z 13 października 2009 roku, w uznaniu wybitnych zasług w działalności społecznej na rzecz osób niewidomych i słabowidzących, została pośmiertnie odznaczona Krzyżem Wielkim Orderu Odrodzenia Polski. W październiku 2017 roku papież Franciszek zatwierdził dekret o heroiczności cnót Matki Elżbiety i tym samym przysługuje jej tytuł Czcigodnej Służebnicy Krzyża.

\section{Dzieto $^{2}$ Lasek w wymiarze tyflologicznym, wychowawczo-apostolskim i społecznym}

Laski $i^{3}$ były jednym z najbardziej znanych i żywych intelektualnie środowisk dwudziestolecia międzywojennego - miejscem powołania do życia zespołu placówek edukacyjnych i społecznych jak również przestrzenią do tworzenia wielu inicjatyw apostolskich: Kółko, księgarnia, wydawnictwo „Verbum”, publikujące pod tym samym tytułem kwartalnik poświęcony problematyce religijnej, filozoficznej, literackiej i społecznej zarazem, Biblioteka Wiedzy Religijnej, ośrodek rekolekcyjny, ośrodek ruchu liturgicznego i odnowy tomizmu (Wyszyński 1946). Miejscem,

2 Tadeusz Mazowiecki (2000, s. 510), próbując ująć to pojęcie, które na trwałe zagościło w kanonie wiedzy o działalności Zgromadzenia FSK i TOnO w Laskach, pisze: „W słowie «dzieło» i w sposobie jego pojmowania była od razu zawarta głębsza treść związana z tym, czym Laski mają być, co określa najbardziej ostateczny cel Dzieła, i z tym, co stanowi o jego charakterze oraz wewnętrznej spójności".

3 Uogólnione pojęcie Laski w rozumieniu tworzenia pewnej kultury filozoficznej, chrześcijańskiej, społecznej i pedagogicznej ubiegłego wieku, ze współczesnymi konotacjami. 
któremu Matka Elżbieta Róża Czacka nadała pojemność ideową, i wreszcie miejscem, w którym realizowano i nadal realizuje się projekt wychowania zakładający istnienie wspólnoty dającej większe możliwości odniesień osobowych oraz przekazu wartości. „[Laski] dawały przykład miłości. Najpierw dostrzegana była życzliwość, otwartość, szacunek, gotowość przyjaźni, z jaką spotykali się zawsze przychodzący tu ludzie. A potem rósł drugi plan, głębszy: przykład miłości prowadzącej do heroicznych ofiar, które wiązały się z tworzeniem i życiem Zakładu. Ofiar, które były widoczne nawet dla osób tu przyjeżdżających, odwiedzających Zakład, a tym bardziej dla stałych bywalców. To Laski dawały. Ale jednocześnie czegoś Laski wymagały. Przede wszystkim wymagały poważnego traktowania wiary" (Cywiński 2000, s. 505).

Życie w Laskach stanowiło współpracę trzech wspólnot: niewidomych, sióstr zakonnych oraz osób świeckich (Triuno: na chwałę Trójcy Przenajświętszej; trzy w jednym). W pismach i życiu Matki E. R. Czackiej często przejawia się troska o zrozumienie tej współzależności, o zbudowanie wspólnej duchowości we wszystkich działach i strukturach Dzieła. We Wstępie do regulaminów dla pracowników Towarzystwa i całego Dzieła w 1945 roku Matka Czacka pisała: „[...] osoby pracujące albo zatracą się w tej całości [,] dodając do niej swoją indywidualność i harmonizując zupełnie z nią, albo też jako ciało obce wywoływać będą choroby w organizmie Dzieła, stanowić będą zgrzyt w jego harmonii” (cyt. za: Podgórska 2011, s. 122). Dzieło Lasek wynikało konsekwentnie z Triuno i tworzone było w trzech wymiarach $^{4}$ : tyflologicznym, wychowawczo-apostolskim i społecznym. Wymiar tyflologiczny ukierunkowany był na wsparcie i realizację potrzeb osób niepełnosprawnych wzrokowo, wychowawczo-apostolski, zorientowany na aktywność w zakresie wychowania, kształcenia i rehabilitacji tej grupy osób z niepełnosprawnością, tj. „takich, którzy poza brakiem wzroku są fizycznie, umysłowo i moralnie zdrowi [działalność nurtu drugiego - przypis aut.], ma z nich uczynić ludzi o szlachetnym, pełnowartościowym charakterze, a także wzorowych pionierów sprawy. Dąży się tutaj do świadomego i konsekwentnego utrzymania tego kierunku, broniąc się przed tendencjami obniżania poziomu dla celów doraźnego miłosierdzia” (cyt. za: Kuczyńska-Kwapisz 2011, s. 44-45). Matka E. R. Czacka zabiegała o wychowanie elit niewidomych, którzy popularyzować będą w przyszłości sprawy swojego środowiska ${ }^{5}$, a także o apostolstwo wśród widzących - „niewidomych na duszy"6. Słowa Janiny Doroszewskiej oddają myśli E. R. Czackiej o elitarnej roli wychowania w Laskach: „mieliśmy - według zaleceń Matki - wychowywać

4 O podstawach ideowych Dzieła pisała Matka E. R. Czacka w Triuno (Czacka 1936).

5 Wspomina o tym również Jadwiga Kuczyńska-Kwapisz (2011, s. 188): „ważnym zadaniem Dzieła było przygotowanie elit, tzn. takich osób niewidomych, które własną pracą i swoim przykładem mogą przyczyniać się do wyższej jakości życia innych ludzi z dysfunkcją wzroku. Cel ten został w pełni osiągnięty" (zob. też: Czacka 2007, s. 285).

6 Rozszerzanie wpływu Dzieła było w dużej mierze także zasługą ojca W. Korniłowicza. 
[niewidomych - przypis aut.] na ludzi świadomych, że mają życie trudniejsze od innych, że został im powierzony ciężar, który - chociaż z trudem - ale muszą «donieść» - jak św. Krzysztof na drugi brzeg rzeki. I nie uronić jego ciężaru, ani się go zaprzeć, udając, że go nie widzą, ani nie narzekać na trudność tego zadania [...]. Musicie tego uczyć nasze dzieci" (cyt. za: Gościmska 1987, s. 15). Pragnieniem Matki E. R. Czackiej było wychowanie osób niewidomych wykształconych, uformowanych charakterologicznie i moralnie, stanowiących elitę w swoim środowisku. To oni mieli stać się wzorcami, byli potrzebni dla nadania właściwego kierunku dalszej rehabilitacji tej grupy osób z niepełnosprawnością. Wymiar społeczny Dzieła oznaczał wsparcie $w$ formie wychowania lub opieki nad osobami niewidomymi moralnie zaniedbanymi, chorymi, ze sprzężoną niepełnosprawnością, będącymi $\mathrm{w}$ podeszłym wieku.

We wstępie do Dyrektorium ${ }^{7}$ E. R. Czacka $(1946$, s. 16) charakteryzuje podstawy istnienia Dzieła: „czerpiąc z doświadczenia tyflofilów Zachodu i korzystając ze zdobyczy tyflologii, datujących się od końca XVIII wieku, inaczej rozumieli tę opiekę założyciele Dzieła niewidomych, gdy w 1910 roku powstawała pierwsza jego placówka. Zadaniem jej było wyszkolenie grupy młodych niewidomych w rzemiośle i w piśmie specjalnym, wydobycie ich z bezczynności, opuszczenia i nędzy i uczynienie z nich możliwie samodzielnych i samowystarczalnych pracowników. W rok później założone zostało Towarzystwo Opieki nad Ociemniałymi, które miało na wzór podobnych istniejących na Zachodzie instytucji objąć liczne dziedziny pomocy niewidomym". Na charakter Dzieła miały wpływ również aktywność i charyzmat E. R. Czackiej i osób współtworzących to Dzieło: A. Marylskiego, który stał się niebawem jej najbliższym świeckim współpracownikiem i przyjacielem (przez 28 lat był kierownikiem wszystkich agend TOnO, w okresie międzywojennym podlegały mu również sprawy szkolenia warsztatowego niewidomych, w 1973 roku przyjął święcenia kapłańskie), ks. W. Korniłowicza (spowiednika sióstr i doradcy w sprawach zgromadzenia FSK i Zakładu dla Niewidomych; jego dziełem było odnowienie liturgii w Laskach, przybliżenie tomizmu, propagowanie i rozwój kwartalnika „Verbum” i Biblioteki Wiedzy Religijnej, był twórcą Kółka dla zainteresowanych filozofią studentów Uniwersytetu Warszawskiego; współtwórcą Stowarzyszenia Katolickiego Odrodzenie), Henryka Ruszczyca (wychowawcy i kierownika Internatu Chłopców, zwolennika nowatorskiej koncepcji rehabilitacji zawodowej osób niewidomych i ociemniałych - Dycht 2012, 2013a), Zygmunta Serafinowicza (wieloletniego nauczyciela i wychowawcy; w latach 1945-1966 kierownika szkół dla niewidomych w Laskach; współpracownika Państwowego Instytutu Pedagogiki Specjalnej utworzonego przez Marię Grzegorzewską w Warszawie)

7 Jest to podstawowy zbiór pism formacyjnych Matki E. R. Czackiej. Zawiera jej listy pisane do Wspólnoty Dzieła lub do Zgromadzenia w latach 1925-1932. Tekst Dyrektorium został w 1965 roku zatwierdzony przez ks. Prymasa Stefana Wyszyńskiego. 
i innych. Rozumienie istoty powołania Dzieła rzutowało z kolei na ich pracę wychowawczą i tyflologiczną w Laskach.

Coraz więcej ludzi należących do kulturalnej elity przedwojennej Polski przyjeżdżało do Lasek, Zakład dla Niewidomych rozwijał się więc intensywnie w wielu kierunkach. Dzieło stale rozszerzało swoją działalność, podejmując wciąż nowe wyzwania. Potrzebowało coraz liczniejszego grona współpracowników, od których wymagano posłuszeństwa, zaakceptowania głównych dyrektyw Dzieła, fachowości i kompetencji do pracy w Laskach w atmosferze wspólnego, opartego na szczerości i zaufaniu dialogu - to wyróżniało ośrodek i owocowało rozwojem zakładu po wojnie. Dbano o dokształcanie kadr pedagogicznych i wychowawczych - sióstr, nauczycieli oraz wychowawców. Początkujący w pracy w Laskach musieli odbyć trzymiesięczny kurs tyflologiczny, prowadzony przez Matkę E. R. Czackąa ${ }^{8}$ Od swoich współpracowników w Dziele Matka E. R. Czacka wymagała konsekwentnie postawy katolickiej. Formacji tyflologicznej towarzyszyła więc także formacja duchowa - wspólny udział w nabożeństwach, spotkania w Kółku prowadzonym przez ks. Korniłowicza, wspólne odmawianie oficjum, rozmowy na tematy religijne i światopoglądowe, czytelnictwo, obecność na różnorodnych wykładach naukowych.

Laski stawały się źródłem duchowym i intelektualnym, przyciągającym ludzi o odmiennych niejednokrotnie ideologiach, miejscem dialogu, ale i wzajemnej akceptacji. „Dla człowieka żyjącego w światopoglądowej próżni było to wiele: docierała doń propozycja i systemu uzasadniającego wiarę, i postawy optymistycznego realizmu, i wskazanie, że możliwe jest przezwyciężenie chaosu i oparcie dla etyki, i uniwersalizm, i szacunek dla osoby" (Cywiński 2000, s. 505).

Refleksja nad człowiekiem w międzywojennej Polsce nawiązywała do myśli chrześcijańskiej św. Augustyna, św. Tomasza z Akwinu czy francuskiego filozofa, Jacques’a Maritaina. Wpływała także na atmosferę intelektualną Lasek'. Pierwszy z wymienionych wyżej myślicieli jest znany z koncepcji pełni osoby ludzkiej, składającej się z duszy i ciała. Człowiek św. Tomasza, będący całością psychofizyczną, hierarchicznie umiejscowiony jest pomiędzy sferą materii i ducha, życia biologicznego i umysłowego. W ramach ludzkiej osoby aspekty materialny i psychiczny są jednakowo ludzkie i niezbędne, zaś dusza jest czynnikiem organizującym i formującym materię (Dziekoński 2011). W przezwyciężaniu wpływu

8 E. R. Czacka pragnęła mieć specjalistów znających najnowsze osiągnięcia naukowe tyflologii. „Chciała, aby wychowawcy i nauczyciele znali nie tylko tyflopedagogikę i tyflopsychologię i dzięki temu wiedzieli, czego można wymagać od osób niewidomych, ale też, aby znali psychologię dziecka z dysfunkcją wzroku i umieli określić możliwości wzrokowe dziecka słabo widzącego" (Kuczyńska-Kwapisz, 2011, s. 152).

9 Sprawy nawiązania do tomizmu i odkrycia na nowo liturgii - bardzo ważne i tak charakterystyczne dla Lasek i ich roli w odrodzeniu religijnym polskiej inteligencji - niejednokrotnie już podjęto i szczegółowo opisywano w wielu opracowaniach: zob. m.in.: K. Tarnowski 2011, s. 57-65; zob. też: publikacje pisane z myślą o osobie i działalności ks. W. Korniłowicza. 
św. Augustyna, który o wiele bardziej odpowiadał polskiej religijności, istotną rolę odegrały w dwudziestoleciu międzywojennym w Polsce pisma i poglądy francuskich tomistów, a szczególnie J. Maritaina, reprezentującego nurt personalizmu chrześcijańskiego, z jednoczesnym nawiązaniem do integralnego humanizmu, który zaproponował szeroką koncepcję Kościoła i nowoczesnego społeczeństwa. Teoria osoby ludzkiej J. Maritaina wskazuje na rozróżnienie w człowieku jednostki i osoby. Człowiek jest bytem (substancją), jednością ducha i ciała, jest materią i bytem niematerialnym, jednocześnie jest nierozdzielną jednością. Jednostka, będąc członkiem społeczności, podporządkowana jest prawom społeczeństwa i państwa w sferze materialnej, ekonomicznej i politycznej egzystencji. Jako osoba natomiast człowiek wykracza poza społeczeństwo, góruje, dominuje nad nim w sferze transcendencji, nadprzyrodzonych aspiracji do zbawienia, związanych z życiem osobowym. Personalizm Maritaina głosił bezwzględny prymat osoby ludzkiej nad społeczeństwem, której godność wynika nie z faktu podporządkowaniu państwu, lecz z jej własnej metafizycznej istoty (Maritain 1936). Poglądy Maritaina sytuują go wśród zwolenników ustroju demokratycznego, jako najbliższego zasadom ewangelicznym, gwarantującego podmiotowość ludzi.

W Laskach miała miejsce orientacja na kulturę intelektualną w kierunku integralnej chrześcijańskiej formacji człowieka. Wykłady z tomizmu prowadził dla sióstr służebnic Krzyża w Laskach ks. Korniłowicz. Zarówno J. Maritain, jak i Charles Journet bywali w przedwojennych Laskach jako prelegenci ${ }^{10}$.

Wśród dzieł religijnych Lasek należy wymienić Odrodzenie - Katolickie Stowarzyszenie Młodzieży Akademickiej, działające głównie we Lwowie i Wilnie. Powołane do życia przez ojca Korniłowicza (wespół z Adamem Korybutem Woronieckim), podjęło ważne studia nad Biblią, liturgią, teologią i filozofią tomistyczną (Tarnowski 2011). Do Odrodzenia należeli Stanisław Stomma i Jerzy Turowicz: redaktorzy i publicyści „Tygodnika Powszechnego”, miesięcznika „Znak” oraz Stefan Świeżawski (twórca szkoły tomizmu lubelskiego). W powojennej Polsce odegrali oni ważną rolę w konstytuowaniu się filozofii personalistycznej. J. Turowicz, S. Stomma i S. Świeżawski byli częstymi gośćmi Lasek. Lwowskie i wileńskie Odrodzenie i Laski zapoczątkowały w Polsce nurt tzw. katolicyzmu otwartego, krzewiącego personalizm ukierunkowany na szacunek do człowieka pojmowanego zawsze jako cel, nie zaś środek, w którym panuje wolność Kościoła ekumenicznego (Dembowski 2011), otwartego na świeckich, inaczej myślących czy wierzących. W tym znaczeniu duch, atmosfera Lasek to synonimy najlepszych tradycji polskiego katolicyzmu, „miejsce poważnego traktowania wiary” (Cywiński 2000, s. 505).

10 Wpływ tomizmu był bardzo widoczny w życiu ks. Korniłowicza. „Przenikał jego umysł, styl pracy i oddziaływanie duszpasterskie" (Żółtowski 1999, s. 127). W biografiach ojca duchowego Matki Czackiej wskazuje się na bliskie osobiste związki W. Korniłowicza z Jacques’em i Raissą Maritainami (Landy, Wosiek 2003, s. 153-155; Tarnowski 2011, s. 59). 
Ważną inicjatywą ks. Korniłowicza, powołanego do pracy w Kurii Metropolitańskiej, był utworzony przez niego jesienią 1918 roku w Warszawie zalążek słynnej później wspólnoty inteligenckiej, zwanej potocznie Kółkiem. Zrzeszenie skupiało młodą inteligencję polską (w większości byli to niewierzący lub nowo nawróceni w różnym wieku, o odmiennych często przekonaniach politycznych, społecznych; poeci, artyści, prawnicy, lekarze, przedstawiciele organizacji katolickich) prowadzącą różnorodne, żarliwe dyskusje na tematy naukowe i religijne (zwłaszcza dotyczące studium św. Tomasza z Akwinu). Z rzadka tylko poruszano kwestie polityczne, „[...] z pasją szukając prawdy, sensu życia, dobra i piękna” (Krokos 2011, s. 212). Inne ośrodki uniwersyteckie w kraju i za granicą odwoływały się do działalności Koła, jego członkowie zaś często po okresie gorących i twórczych poszukiwań teoretycznych i w zakresie wiary wcielali w realne życie syntezę swych poszukiwań - angażowali się w działalność na rzecz niewidomych w Laskach, współpracowali z Patronatem, pomagając w różnej formie osobom niewidomym z okolic Warszawy (Żółtowski 1999).

Ponadto pod wpływem autentycznej charyzmy ks. Korniłowicza powstał także, w 1933 roku, Instytut Kultury Chrześcijańskiej i czasopismo „Verbum”, które publikowało studia filozoficzne, teologiczne, tłumaczenia dzieł J. Maritaina, C. Journeta, Oliviera Augusta Lacombe'a i innych (Landy, Wosiek 2003). Szczególnie J. Maritain wywarł wpływ na tę wersję tomizmu, jaką pod kierunkiem ks. Korniłowicza propagowało „Verbum”. Także i te środowiska - Odrodzenia, „Verbum” i Kółka - zaowocowały w naturalny sposób powołaniami do współpracy z Dziełem Lasek. Z nich rekrutowali się pierwsi pedagodzy, pierwsze Franciszkanki Służebnice Krzyża oraz bracia III Zakonu św. Franciszka (Żółtowski 1999; Krokos 2011; Wosiek 2011).

Za sprawą indywidualnego duszpasterstwa ojca Korniłowicza możliwe stało się zetknięcie praktycznego realizmu, zgodnego z duchem idei św. Franciszka z Asyżu, z realizmem filozoficznym św. Tomasza z Akwinu, tomizmu i odnowionej liturgii (opartej na wzorach benedyktyńskich) z Dziełem Lasek. Dzięki temu możliwe było zespolenie założeń zakonu Sióstr Franciszkanek Służebnic Krzyża z działalnością na rzecz wsparcia osób niewidomych. „Dlatego też te dwa Dzieła, uzupełniające się wzajemnie, przy pierwszym zetknięciu samorzutnie i organicznie zespoliły się w jedno (Czacka 2000, s. 535). Miejsce to pozostawiło ślad w kulturze i w życiu duchowym wielu niezwykłych ludzi: m.in.: Zofii Landy (s. Teresy), Zofii Steinberg (s. Katarzyny), Zofii Sokołowskiej (s. Katarzyny), Bronisławy Agnieszki Wajngold (s. Marii Gołębiowskiej), Wiesławy Walickiej-Woyczyńskiej (s. Benedykty), A. Marylskiego, Z. Serafinowicza, Witolda Bronisława Świątkowskiego, Antoniego Bogusława Marii Rostworowskiego. Zofia Wyrzykowska (2002, s. 36) potem napisze: „rósł ideowy zespół młodych ludzi pracujących bezpłatnie, tylko za skromne, często niewystarczające utrzymanie, nieliczących się z godzinami pracy, niemających osobistego życia, a oddających wszystkie siły sprawie niewidomych. Ludzie ci zżyli się ze sobą, stosunki były pełne prostoty, szczerości i wzajemnego zaufania”. 


\section{Podsumowanie}

Reasumując, Matka Elżbieta poprzez swoją działalność diametralnie zmieniła sytuację osób z niepełnosprawnością narządu wzroku. Dbała o ich kształcenie, wychowanie, dawała im wsparcie duchowe, umożliwiała zdobycie zawodu i przygotowanie do samodzielnego życia. Założyła Towarzystwo Opieki nad Ociemniałymi, które prowadzi i dzisiaj specjalne placówki edukacyjne i rehabilitacyjne. Powołała do życia Zgromadzenie Sióstr Franciszkanek Krzyża, którego głównym celem jest wszechstronna działalność na rzecz osób niewidomych przy współpracy z TOnO. Prowadziła prace badawcze nad dostosowaniem pisma Braille’a i jego skrótów do zasad języka polskiego. Wyniki tych poszukiwań znalazły akceptację władz oświatowych, przyczyniając się do rozwoju wydawnictw stosujących druk wypukły i do upowszechnienia wśród osób niewidomych czytelnictwa. Opisała sposób wychowania i kształcenia niewidomego dziecka. Opracowała wytyczne w formie memoriałów dla instytucji rządowych w celu wypracowania lepszych rozwiązań prawnych dotyczących osób z niepełnosprawnością narządu wzroku.

Przyjmując interpretację historyczną bądź sytuacyjną, Dzieło, albo inaczej doświadczenie Lasek, trzeba ujmować jako wydarzenie niepowtarzalne przy wszelkich opisach konkretnego doświadczenia wychowawczego (Nowak 2010, 2011). Takie podejście plasuje Zakład dla Niewidomych w Laskach obok doświadczenia oratorium ks. Jana Bosko, doświadczenia szkoły ks. Lorenzo Milani w Calenzano i Barbiana we Włoszech, doświadczenia Johanna Heinricha Pestalozziego, Lwa Tołstoja czy Janusza Korczaka. Pozwala wskazać możliwości jego pojmowania, przestrzeń, w której to doświadczenie przebiega i inspirującą jego rolę w działalności edukacyjnej. Może ono oznaczać zarówno kategorię pewnego wymiernego efektu - sukcesu wychowawczego Lasek, jak i pewną nie do końca pojmowalną i określoną atmosferę wychowawczą Dzieła, która - co podkreśla J. Kuczyńska-Kwapisz (2011) - szczyci się ponad stuletnim okresem działania oraz ciągłym rozwojem i wysokim poziomem utworzonych instytucji. Miały one charakter pedagogiczny, rehabilitacyjny, ale ponadto naukowy i badawczy. Stanowią pewien fenomen: połączenie nauki tyflologicznej z wykładnią Kościoła katolickiego. Waga założeń wychowawczych Dzieła Lasek jest porównywana przez niektórych z teorią i praktyką pedagogiczną Marii Montessori (Tarnowski 2011) oraz z działalnością twórczyni polskiej szkoły pedagogiki społecznej - Heleny Radlińskiej (Stanowski 200o).

\section{Bibliografia}

Cywiński B. (200o). Laski w oczach współczesnych. W: Mazowiecki T. (oprac.). Ludzie Lasek. Warszawa: Biblioteka „Więzi”.

Czacka E. R. (1932a). Memoriał w Sprawie wychowania i kształcenia niewidomych (mps). Laski: Biblioteka Tyflologiczna. 
Czacka E. R. (1932b). Memoriat o Sprawie niewidomych $w$ Polsce (Memoriat Rockefellerowski) (mps). Laski: Biblioteka Tyflologiczna.

Czacka E. R. (1936). Triuno. Tekst z 24 stycznia (mps). Laski: Biblioteka Tyflologiczna.

Czacka E. R. (1937). Memoriał w Sprawie całości Dzieła (mps). Laski: Biblioteka Tyflologiczna.

Czacka E. R. (1938). Memoriał w Sprawie możliwości Komitetu Porozumiewawczego (mps). Laski: Biblioteka Tyflologiczna.

Czacka E. R. (1946). Dzieło niewidomych. „Caritas”, nr 10, s. 16-17.

Czacka E. R. (200o). Triuno. Laski, tekst z 24 stycznia 1936 roku. W: Ludzie Lasek. Mazowiecki T. (oprac.). Warszawa: Biblioteka „Więzi”.

Czacka E. R. (2007). Zgromadzenie Sióstr Franciszkanek Służebnic Krzyża. Notatka z 17 stycznia 1927 roku. W: Matka Elżbieta Czacka. Dyrektorium. Banaszek M., Prussak M., Michalak K. (red.). Warszawa: UKSW.

Czacka R. (2011). Historia Triuno. Laski, tekst z 1936 roku. W: Kuczyńska-Kwapisz J. Wkład Matki Elżbiety Róży Czackiej w rozwój tyflologii w kontekście współczesnej recepcji jej myśli (aneksy). Warszawa: UKSW.

Czacka E. R., Landy T. (1932). Memoriał w Sprawie opieki nad niewidomymi (mps). Laski-Różanna (prawdopodobnie napisany przed 1932). Laski: Biblioteka Tyflologiczna.

Dembowski B. (2011). Środowisko przy kościele św. Marcina w czasach PRL-u. W: Środowisko Lasek w perspektywie historii i chrześcijańskiej myśli pedagogicznej. Placha J. (red.). Warszawa: UKSW.

Dycht M. (2012). Henryk Ruszczyc. Pedagogiczne inspiracje. Warszawa: UKSW.

Dycht M. (2013a). Henryk Ruszczyc i Jego koncepcja rehabilitacji zawodowej niewidomych. „Szkoła Specjalna”, nr 3, s. 165-173.

Dycht M. (2013b). Koncepcja wychowania Henryka Ruszczyca na tle uznanych systemów pedagogicznych. „Laski” 2013, R. XIX, nr 6 (116), s. 48-81.

Dziekoński S. (2011). Teologiczny aspekt sensu cierpienia. W: Środowisko Lasek w perspektywie historii i chrześcijańskiej myśli pedagogicznej. Placha J. (red.). Warszawa: UKSW.

Gościmska A. (1987). Matka Czacka jako wychowawca. Z sesji Ośrodka SzkolnoWychowawczego, notatka z 28 sierpnia (mps). Laski: Archiwum H. Ruszczyca.

Gościmska A., Żółtowski M. (2004). Historia działalności Towarzystwa Opieki nad Ociemniałymi w Laskach w latach 1961-1976. Laski: TOnO.

Grodecka E. (1996). Historia niewidomych polskich w zarysie. Warszawa: PZN.

Krokos J. (2011). Filozofia w stużbie pedagogiki. W: Środowisko Lasek w perspektywie historii i chrześcijańskiej myśli pedagogicznej. Placha J. (red.). Warszawa: UKSW.

Kuczyńska-Kwapisz J. (2011). Wkład Matki Elżbiety Róży Czackiej w rozwój tyflologii w kontekście współczesnej recepcji jej myśli. Warszawa: UKSW.

Kuczyńska-Kwapisz J. (2018). Założenia tyflologiczne Róży Czackiej i ich ponadczasowe znaczenie z perspektywy stuletniej działalności Zgromadzenia Sióstr Franciszkanek Stużebnic Krzyża. „Forum Pedagogiczne”, nr 2, s. 139-151. 
Landy T., Wosiek R. (2003). Ksiądz Władysław Korniłowicz. Warszawa: Biblioteka "Więzi”.

Maritain J. (1936). Humanisme intégral. Paris: Fernand Aubier.

Mazowiecki T. (2000). Laski niewidomych i widzacych. W: Ludzie Lasek. Mazowiecki T. (oprac.). Warszawa: Biblioteka „Więzi”.

Nowak M. (2010). Doświadczenie dialogu w tworzeniu wiedzy pedagogicznej. W: Pedagogika dialogu w rzeczywistości XXI wieku. Dąbrowa E., Jankowska D. (red.). Warszawa: APS.

Nowak M. (2011). Interdyscyplinarny klucz w teorii i praktyce pedagogicznej Lasek. Środowisko Lasek w perspektywie historii i chrześcijańskiej myśli pedagogicznej. W: Placha J. (red.). Warszawa: UKSW.

Podgórska R. (2011). Wymiar społeczny i religijny $w$ formacji osoby niewidomej w pismach i działalności Matki Elżbiety Róży Czackiej. W: Środowisko Lasek $w$ perspektywie historii i chrześcijańskiej myśli pedagogicznej. Placha J. (red.). Warszawa: UKSW.

Stanowski A. (200o). Miłość odważna i wymagająca. Dzieło Matki Elżbiety Czackiej jako czynnik odrodzenia religijnego. W: Ludzie Lasek. Mazowiecki T. (oprac.). Warszawa: Biblioteka „Więzi”.

Tarnowski J. (2011a). Paradoks chrześcijańskiej pedagogiki. W: Środowisko Lasek $w$ perspektywie historii i chrześcijańskiej myśli pedagogicznej. Placha J. (red.). Warszawa: UKSW.

Tarnowski K. (2011b). Personalizm francuski a Dzieło Lasek. W: Środowisko Lasek $w$ perspektywie historii i chrześcijańskiej myśli pedagogicznej. Placha J. (red.). Warszawa: UKSW.

Wosiek R. (2011). Aktualność przesłania księdza Władysława Korniłowicza. W: Środowisko Lasek $w$ perspektywie historii i chrześcijańskiej myśli pedagogicznej. Placha J. (red.). Warszawa: UKSW.

Wyrzykowska Z. (2002). Historia 50-letniej działalności 1910-1960 Towarzystwa Opieki nad Ociemniałymi w Laskach. Żółtowski M. (przypisy, oprac.). Laski: TOnO.

Wyszyński S. (1946). Ks. Władysław Korniłowicz. „Tygodnik Powszechny”, nr 50 (15 lipca), s. 1-3.

Żółtowski M. (1999). Blask prawdziwego światła. Matka Elżbieta Róża Czacka i jej dzieło. Lublin: ER-ART.

\section{MOTHER ELIZABETH - RÓŻA CZACKA'S EDUCATION OF THE VISUALLY IMPAIRED: THEORY AND PRACTICE}

Abstract: The article presents life and work of Róża Maria Czacka's. She was a seminal figure for education and rehabilitation of blind and visually impaired people in Poland, and she was a creator of modern institutions that follow best practice and are exemplification of her 
theoretical concepts and assumptions. The article describes Mother Elizabeth's "Creation", taking its scientific and pragmatic contexts into consideration. Rehabilitation and social initiatives, supporting people with vision concerns and activities resulting in a creation of global, systemic solutions in the area of social and educational policies related to the group of people with this kind of disability, place Róża Maria Czacka among prominent figures of Polish special education, including visual impairments.

Keywords: Róża Czacka; Mother Elisabeth; blind person; partially sighted; education.

Jadwiga Kuczyńska-Kwapisz - profesor zwyczajny. Kieruje Katedrą Pedagogiki Specjalnej, Przedszkolnej i Wczesnoszkolnej. Od 2009 roku jest ekspertem PKA. Pracuje również w Zespole Pedagogiki Specjalnej przy Polskiej Akademii Nauk. Wypromowała 12 doktorów nauk humanistycznych i społecznych. Przez dwie kadencje (1996-2002) była prorektorem ds. badań i współpracy zagranicznej w Akademii Pedagogiki Specjalnej. W latach 2005-2008 pełniła funkcję dziekana Wydziału Nauk Humanistycznych Uniwersytetu Kardynała Stefana Wyszyńskiego, a następnie (2008-2016) dziekana Wydziału Nauk Pedagogicznych UKSW. W latach 1999-2009 pełniła funkcję redaktora naczelnego „Szkoły Specjalnej”. Jej zainteresowania naukowo-badawcze dotyczą edukacji i rehabilitacji osób z niepełnosprawnością, a szczególnie niewidomych i słabowidzących. Opublikowała ok. 90 prac dotyczących pedagogiki specjalnej, w tym: Wkład Matki Elżbiety Róży Czackiej w rozwój tyflologii w kontekście współczesnej recepcji jej myśli (2011), Rehabilitacja osób niewidomych i słabo widzacych. Przewodnik metodyczny (1996), Efektywność kształcenia młodzieży niewidomej i słabowidzacej $w$ zakresie orientacji przestrzennej i poruszania się (1995). Adres korespondencyjny: Wydział Nauk Pedagogicznych UKSW, ul. Wóycickiego 1/3, 01-938 Warszawa. Adres e-mailowy: jk-kwapisz@wp.pl.

Marzena Dycht - profesor nadzwyczajny na Wydziale Nauk Pedagogicznych UKSW w Warszawie, doktor habilitowany nauk społecznych. Tyflopedagog. Autorka czterech publikacji naukowych i wielu artykułów polskich i zagranicznych z zakresu pedagogiki specjalnej i szczegółowej jej subdyscypliny - tyflopedagogiki. Koordynator i główny wykonawca projektów naukowych z zakresu pedagogiki specjalnej. Kierownik studiów podyplomowych pod nazwą Pedagogika Osób z Niepełnosprawnością Intelektualną i Tyflopedagogika na WNP UKSW. Członek Zespołu Pedagogiki Specjalnej Polskiej Akademii Nauk. Zainteresowania naukowe: edukacja, rehabilitacja wzroku, kompleksowe wsparcie dzieci niewidomych i słabowidzących, wyrównywanie szans edukacyjnych uczniów z dysfunkcją wzroku - edukacja włączająca i specjalna - w ujęciu historycznym i systemowym, system punktowy Louisa Braille’a - zapis integralny i skrótowy, zagraniczne systemy, tożsamość współczesnej pedagogiki specjalnej, w tym tyflopedagogiki. Adres korespondencyjny: Wydział Nauk Pedagogicznych UKSW, ul. Wóycickiego 1/3, 01-938 Warszawa. Adres e-mailowy: m.dycht@uksw.edu.pl. 